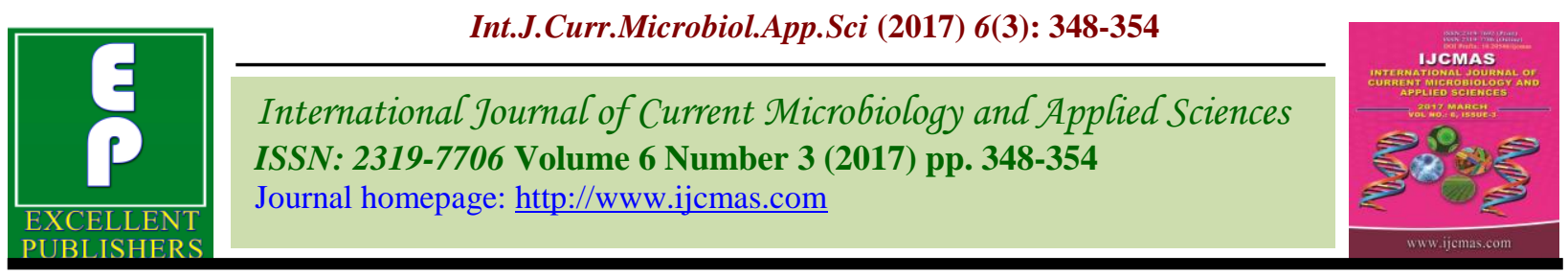

Original Research Article

https://doi.org/10.20546/ijcmas.2017.603.039

\title{
Impact of Knowledge on Adoption of Integrated Pest Management Practices by Sugarcane Growers
}

\author{
Roop Kumar, R.N. Yadav, Manoj Kumar, Amit Kumar Mishra, \\ Akshay Kumar and Kshitij Parmar
}

\author{
Department of Agricultural Extension, College of Agriculture, SVPUA\&T, \\ Modipuram Meerut (U.P) 250110, India \\ *Corresponding author
}

\begin{tabular}{|c|c|}
\hline & A B S T R A C T \\
\hline $\begin{array}{l}\text { IPM, Sugarcane, } \\
\text { Knowledge, } \\
\text { Adoption. }\end{array}$ & \multirow{3}{*}{$\begin{array}{l}\text { The study was carried out during } 2013-14 \text { in Meerut district of Uttar Pradesh state to focus } \\
\text { on the sugarcane growers regarding impact of knowledge on adoption level of IPM } \\
\text { practices. The } 80 \text { contact farmers were selected as respondents. The study revealed that the } \\
\text { maximum knowledge gap was found to be existing in previous crop residues, crop } \\
\text { rotation, hand picking of the insect and their destruction, hot air and water treatment, light } \\
\text { and pheromone trap, microbial control, use of natural enemies, resistant varieties, bio- } \\
\text { pesticides/ bio-agents, application and dose of different pest etc. The maximum adoption } \\
\text { gap was found to be removal of the previous crop residues, inter cropping, crop rotation, } \\
\text { hot air and water treatment, hand picking of pest and their destruction, lights traps, } \\
\text { microbial control, natural enemies, resistant varieties, use of hormone, seed treatment, soil } \\
\text { treatment etc. The result implies that sugarcane growers with more knowledge have more } \\
\text { adoption level of cultural, mechanical, biological and chemical methods of IPM practices. }\end{array}$} \\
\hline Article Info & \\
\hline $\begin{array}{l}\text { Accepted: } \\
\text { 10 February } 2017 \\
\text { Available Online: } \\
10 \text { March } 2017\end{array}$ & \\
\hline
\end{tabular}

\section{Introduction}

It is universally acknowledged that India is the homeland of sugarcane and sugar. The sugar is the focal source of sucrose in the diet of human being all over the world. Sugar juice is used for making white sugar, brown sugar (khandsari) and jiggery (gur). Sugarcane is one of the main crop of earning foreign exchange. It is a major source of energy with $1 \mathrm{~kg}$ of sugar capable of yielding as much as $3900 \mathrm{kcal}$. The main byproducts of sugarcane industry are begasses and molasses. Sugarcane is grown is diversified climate condition tropical and subtropical. Out of 115 countries of world where sugarcane is cultivated. India is the only one in which both type climate found. Among 115 countries in sugarcane cultivation India rank first in terms of area 5.09 million hectare, production 357.67 million tonnes and its productivity 70.31 tonnes / hectare (Directorate of economics and statistics, department of agriculture and corporation.).

Integrated pest management is one of the components of sustainable agriculture. IPM is a broad ecological pest control measure to keep the pest control measure to keep the pest population below the economic threshold level (ETL). The philosophy of IPM did not percolate down to the farmers for quite a long 
time, after its presentations and prescription for solving pest problem in modern agriculture. An IPM practice includes cultural, mechanical and biological method of pest control while the chemical are used as a last result.

IPM approach of agriculture presence biodiversity, maintain soil fertility and water purity, consume and improve the chemical physical and biological control qualities of soil, recycle nature resource and consume energy. This has not only improved the socioeconomic structure of the farming community but has also helped in saving the environment from being polluted. The study was conducted with the following objectives: to study the knowledge and adoption of IPM practices by sugarcane growers and to study the impact of knowledge on adoption of IPM practices by sugarcane growers.

\section{Materials and Methods}

The study was conducted in Meerut district of Uttar Pradesh. The study is based on the primary data, collected for the year 2013-14 from the 12 community development block out of which two blocks namely Sardhana and Daurala were purposively selected, because these block have more area under sugarcane crop. Four villages were selected purposively from each block; ten respondents from each village were randomly selected, thus making a total size of 80 respondents for the study.

A structured interview schedule was used to collect data from the respondent by personal interview method. The obtained data were analysed with the help of frequency percentage and correlation coefficient (r). The Karl Pearson's following formula of correlation coefficient was used to find out the relation between knowledge and adoption level of sugarcane growers regarding IPM practices. Formula of correlation coefficient (r) is as follows:

$$
\mathrm{r}=\frac{\sum \mathrm{XY}}{\sqrt{\left(\sum X\right)^{2}\left(\sum Y\right)^{2}}}
$$

Where

$\mathrm{X}=\mathrm{X}-\overline{\overline{\mathrm{X}}}$

$\mathrm{Y}=\mathrm{Y} \overline{\mathrm{Y}}$

\section{Results and Discussion}

\section{Relationship between knowledge and adoption of cultural methods of IPM practices}

Table 1 shows, the majority of the respondents 51.25 percent belonged to fully known category about summer deep hoeing. The 63.75 percent respondents belong to partially known category followed by 32.50 percent respondents belongs to fully known about proper planting distance in timely and late sowing. The 58.75 percent respondents belonged to partially known category followed by 37.50 percent respondents to fully known about the recommended seed rate. The 77.50 percent respondents belonged to partially known category followed by 13.75 percent respondents belonged to fully known about removal of previous crop residues.

The 67.50 percent respondents belonged to partially known category followed by 25.00 percent respondents belonged to fully known about the crop rotation. The 65.00 percent respondents belonged to partially known category followed by 31.25 percent respondents belonged to fully known about the advantages of intercropping.

The maximum 63.75 percent respondents reported under medium level adoption of summer hoeing. The 71.25 percent respondents were medium level adopters followed by 17.50 percent high level about the proper planting distance in timely and late 
sowing. The 65.00 percent respondents were medium level adopters followed by 23.75 percent high level category about the recommended seed rate in timely and late sowing of sugarcane crop. The 63.75 percent respondents were reported under medium level of adoption followed by 27.50 percent respondents were low level category about the removal of previous crop residues. The 56.25 percent respondents were reported under medium level of adopters use of crop rotation followed by 22.50 percent respondents belonged low level of adoption. The 50.00 percent respondents were reported under medium level of adoption followed by 36.25 percent respondents was low adoption level category about the use of inter cropping in sugarcane.

It is evident from the results that out of six the five cultural methods of knowledge regarding IPM practices were positively and highly significantly correlated with the adoption level of sugarcane growers at $5 \%$ level.

\section{Relationship between knowledge and adoption of mechanical methods of IPM practices}

Table 2 reveals that the maximum 78.75 percent belonged to partially known category about rouging practices in sugarcane crop. The 45.00 percent respondents were belonged to partially known about the light and pheromone trap followed by 43.75 percent respondents were belonged to unknown category. The 51.25 percent respondents were belonged to not known followed by 41.25 percent respondents were belonged to partially known category about hand picking of the insect and their destruction. The 52.50 percent respondents were belonged under partially known followed by 41.25 percent respondents were belonged under unknown category about the hot water treatment. The 70.00 percent respondents were belonged to partially followed by 25.00 percent respondents were belonged to not known category about the pest monitoring in sugarcane crop. The 51.25 percent respondents were belonged to not known followed by 40.00 percent respondents were belonged to partially known category about the hot air treatment. The 78.75 percent respondents were medium adoption the rouging practices in sugarcane crop. The 63.75 percent respondents were low adopting use of light trap followed by 26.25 percent respondents were medium adoption. The 73.75 percent respondents were low adoption followed by 23.75 percent respondents were medium about the using hand picking of pest and their destruction. The 67.50 percent respondents were low adoption followed by 28.75 percent respondents were medium adoption about the use of hot water treatment in sugarcane crop. The 60.00 percent respondents were medium adoption level about pest monitoring followed by 33.75 percent respondents were low level of adoption about pest monitoring in sugarcane crop. The 86.25 percent respondents were under low level adoption followed by 12.50 percent respondents were belonged to medium level of adoption about the use of hot air treatment in sugarcane crop.

It is evident from the results the out of six the four mechanical methods of IPM practices regarding knowledge were positively and highly significantly correlated with the adoption level of sugarcane growers at 5\% level.

\section{Relationship between knowledge and adoption of biological methods of IPM practices}

Table 3 reveals that the 77.50 percent respondents belonged to partially known category about the bio-pesticides. The 71.25 percent respondents were belonged to 
partially followed by 18.75 percent respondents belonged to not known category about bio-agents. The 67.50 percent respondents were under partially known category followed by 30.00 percent respondents were under fully known category about bio-fertilizer in sugarcane crop. The 42.50 percent respondents were belonged to partially known category followed by 31.25 percent respondents were belonged to not known category about natural enemies. The maximum 67.50 percent respondents were under partially known category about resistant varieties in sugarcane crop. The 51.25 percent respondents were under not known category followed by 38.75 percent respondents were under partially known category about microbial control.

The 65.00 percent respondents under medium adoption of bio-pesticides in sugarcane crop, the 58.75 percent respondents were medium adoption followed by 37.50 percent respondents were low adoption of bio-agents. The 70.00 percent respondents were medium adoption level of bio-fertilizer in sugarcane crop. The 60.00 percent respondents belonged to low adopting followed by 33.75 percent respondents belonged to medium adoption of natural enemies. The 48.75 percent respondents under medium adoption of resistant varieties followed by 43.75 percent respondents under low adoption, the maximum 66.25 percent respondents under low adoption of microbial control in sugarcane crop.

It is evident from the result that out of six the five biological methods of knowledge regarding IPM practices were positively and highly significantly correlated with the adoption level of sugarcane growers at 5\% level.

Table.1 Correlation coefficient between knowledge and adoption of cultural methods of IPM practices

\begin{tabular}{|c|c|c|c|c|c|c|c|}
\hline \multirow[b]{2}{*}{$\begin{array}{l}\text { Recommended IPM } \\
\text { practices }\end{array}$} & \multicolumn{3}{|c|}{ Knowledge } & \multicolumn{3}{|c|}{ Adoption } & \multirow[b]{2}{*}{$\begin{array}{l}\text { Correlatio } \\
\text { n co- } \\
\text { efficient }\end{array}$} \\
\hline & $\begin{array}{l}\text { Fully } \\
\text { known }\end{array}$ & $\begin{array}{l}\text { Partially } \\
\text { known }\end{array}$ & $\begin{array}{l}\text { Not } \\
\text { know } \\
\mathrm{n}\end{array}$ & $\begin{array}{l}\text { High } \\
\text { level }\end{array}$ & $\begin{array}{l}\text { Medium } \\
\text { level }\end{array}$ & $\begin{array}{l}\text { Low } \\
\text { level }\end{array}$ & \\
\hline \multirow{5}{*}{$\begin{array}{l}\text { Summer hoeing } \\
\text { Proper planting } \\
\text { distance in timely and } \\
\text { late sowing } \\
\text { Recommended seed } \\
\text { rate } \\
\text { Removal of previous } \\
\text { crop residues } \\
\text { Crop rotation }\end{array}$} & $\begin{array}{l}41 \\
51.25\end{array}$ & $\begin{array}{l}38 \\
47.50\end{array}$ & $\begin{array}{l}1 \\
1.25\end{array}$ & $\begin{array}{l}25 \\
31.25\end{array}$ & $\begin{array}{l}51 \\
63.75\end{array}$ & $\begin{array}{l}4 \\
5.00\end{array}$ & $+0.794^{*}$ \\
\hline & $\begin{array}{l}26 \\
32.50\end{array}$ & $\begin{array}{l}51 \\
63.75\end{array}$ & $\begin{array}{l}3 \\
3.75\end{array}$ & $\begin{array}{l}14 \\
17.50\end{array}$ & $\begin{array}{l}57 \\
71.25\end{array}$ & $\begin{array}{l}9 \\
11.25\end{array}$ & $+0.919 *$ \\
\hline & $\begin{array}{l}30 \\
37.50\end{array}$ & $\begin{array}{l}47 \\
58.75\end{array}$ & $\begin{array}{l}3 \\
3.75 \\
\end{array}$ & $\begin{array}{l}19 \\
23.75\end{array}$ & $\begin{array}{l}52 \\
65.00 \\
\end{array}$ & $\begin{array}{l}9 \\
11.25 \\
\end{array}$ & $+0.908^{*}$ \\
\hline & $\begin{array}{l}11 \\
13.75 \\
\end{array}$ & $\begin{array}{l}62 \\
77.50\end{array}$ & $\begin{array}{l}7 \\
8.75 \\
\end{array}$ & $\begin{array}{l}7 \\
8.75 \\
\end{array}$ & $\begin{array}{l}51 \\
63.75 \\
\end{array}$ & $\begin{array}{l}22 \\
27.50\end{array}$ & $+0.918^{*}$ \\
\hline & $\begin{array}{l}20 \\
25.00 \\
\end{array}$ & $\begin{array}{l}54 \\
67.50 \\
\end{array}$ & $\begin{array}{l}6 \\
7.50 \\
\end{array}$ & $\begin{array}{l}17 \\
21.25 \\
\end{array}$ & $\begin{array}{l}45 \\
56.25 \\
\end{array}$ & $\begin{array}{l}18 \\
22.50 \\
\end{array}$ & $+0.949 *$ \\
\hline Inter cropping & $\begin{array}{l}25 \\
31.25\end{array}$ & $\begin{array}{l}52 \\
65.00\end{array}$ & $\begin{array}{l}3 \\
3.75\end{array}$ & $\begin{array}{l}11 \\
13.75\end{array}$ & $\begin{array}{l}40 \\
50.00\end{array}$ & $\begin{array}{l}29 \\
36.25\end{array}$ & +0.429 \\
\hline
\end{tabular}

*Significant at $5 \%$ level 
Table. 2 Correlation coefficient between knowledge and adoption of mechanical methods of IPM practices

\begin{tabular}{|c|c|c|c|c|c|c|c|}
\hline \multirow[b]{2}{*}{$\begin{array}{l}\text { Recommended IPM } \\
\text { practices }\end{array}$} & \multicolumn{3}{|c|}{ Knowledge } & \multicolumn{3}{|c|}{ Adoption } & \multirow[b]{2}{*}{$\begin{array}{l}\text { Correlation } \\
\text { co-efficient }\end{array}$} \\
\hline & $\begin{array}{l}\text { Fully } \\
\text { known }\end{array}$ & $\begin{array}{l}\text { Partially } \\
\text { known }\end{array}$ & $\begin{array}{l}\text { Not } \\
\text { known }\end{array}$ & $\begin{array}{l}\text { High } \\
\text { level }\end{array}$ & $\begin{array}{l}\text { Mediu } \\
\mathrm{m} \text { level }\end{array}$ & $\begin{array}{l}\text { Low } \\
\text { level }\end{array}$ & \\
\hline Bio-pesticides & $\begin{array}{l}11 \\
13.75\end{array}$ & $\begin{array}{l}62 \\
77.50\end{array}$ & $\begin{array}{l}7 \\
8.75\end{array}$ & $\begin{array}{l}5 \\
6.25\end{array}$ & $\begin{array}{l}52 \\
65.00\end{array}$ & $\begin{array}{l}23 \\
28.75\end{array}$ & $+0.898 *$ \\
\hline Bio-agents & $\begin{array}{l}8 \\
10.00\end{array}$ & $\begin{array}{l}57 \\
71.25\end{array}$ & $\begin{array}{l}15 \\
18.75\end{array}$ & $\begin{array}{l}3 \\
3.75\end{array}$ & $\begin{array}{l}47 \\
58.75\end{array}$ & $\begin{array}{l}30 \\
37.50\end{array}$ & $+0.867 *$ \\
\hline Bio-fertilizers & $\begin{array}{l}24 \\
30.00\end{array}$ & $\begin{array}{l}54 \\
67.50\end{array}$ & $\begin{array}{l}2 \\
2.50\end{array}$ & $\begin{array}{l}18 \\
22.50\end{array}$ & $\begin{array}{l}56 \\
70.00\end{array}$ & $\begin{array}{l}6 \\
7.50\end{array}$ & $+0.979 *$ \\
\hline Natural enemies & $\begin{array}{l}5 \\
6.25\end{array}$ & $\begin{array}{l}50 \\
42.50\end{array}$ & $\begin{array}{l}25 \\
31.25\end{array}$ & $\begin{array}{l}5 \\
6.25\end{array}$ & $\begin{array}{l}27 \\
33.75\end{array}$ & $\begin{array}{l}48 \\
60.00\end{array}$ & +0.455 \\
\hline Resistant varieties & $\begin{array}{l}6 \\
7.50 \\
\end{array}$ & $\begin{array}{l}54 \\
67.50 \\
\end{array}$ & $\begin{array}{l}20 \\
25.00\end{array}$ & $\begin{array}{l}6 \\
7.50 \\
\end{array}$ & $\begin{array}{l}39 \\
48.75\end{array}$ & $\begin{array}{l}35 \\
43.75\end{array}$ & $+0.797 *$ \\
\hline Microbial control & $\begin{array}{l}8 \\
10.00\end{array}$ & $\begin{array}{l}31 \\
38.75\end{array}$ & $\begin{array}{l}41 \\
51.25\end{array}$ & $\begin{array}{l}4 \\
5.00\end{array}$ & $\begin{array}{l}23 \\
28.75\end{array}$ & $\begin{array}{l}53 \\
66.25\end{array}$ & $+0.938 *$ \\
\hline
\end{tabular}

*Significant at 5\% level

Table.3 Correlation coefficient between knowledge and adoption of biological methods of IPM practices

\begin{tabular}{|c|c|c|c|c|c|c|c|}
\hline \multirow[b]{2}{*}{$\begin{array}{l}\text { Recommended IPM } \\
\text { practices }\end{array}$} & \multicolumn{3}{|c|}{ Knowledge } & \multicolumn{3}{|c|}{ Adoption } & \multirow[b]{2}{*}{$\begin{array}{l}\text { Correlation } \\
\text { co- } \\
\text { efficient }\end{array}$} \\
\hline & $\begin{array}{l}\text { Fully } \\
\text { known }\end{array}$ & $\begin{array}{l}\text { Partially } \\
\text { known }\end{array}$ & $\begin{array}{l}\text { Not } \\
\text { known }\end{array}$ & $\begin{array}{l}\text { High } \\
\text { level }\end{array}$ & $\begin{array}{l}\text { Medium } \\
\text { level }\end{array}$ & $\begin{array}{l}\text { Low } \\
\text { level }\end{array}$ & \\
\hline Rouging practices & $\begin{array}{l}15 \\
18.75\end{array}$ & $\begin{array}{l}63 \\
78.75\end{array}$ & $\begin{array}{l}2 \\
2.50\end{array}$ & $\begin{array}{l}9 \\
11.25\end{array}$ & $\begin{array}{l}63 \\
78.75\end{array}$ & $\begin{array}{l}8 \\
10.00\end{array}$ & $+0.982 *$ \\
\hline \multirow{3}{*}{$\begin{array}{l}\text { Use of light and } \\
\text { pheromone trap } \\
\text { Hand picking of the } \\
\text { insect }\end{array}$} & $\begin{array}{l}9 \\
11.25\end{array}$ & $\begin{array}{l}36 \\
45.00\end{array}$ & $\begin{array}{l}35 \\
43.75\end{array}$ & $\begin{array}{l}8 \\
10.00\end{array}$ & $\begin{array}{l}21 \\
26.25\end{array}$ & $\begin{array}{l}51 \\
63.75\end{array}$ & +0.710 \\
\hline & $\begin{array}{l}6 \\
7.50\end{array}$ & $\begin{array}{l}33 \\
41.25\end{array}$ & $\begin{array}{l}41 \\
51.25\end{array}$ & $\begin{array}{l}2 \\
2.50\end{array}$ & $\begin{array}{l}19 \\
23.75\end{array}$ & $\begin{array}{l}59 \\
73.75\end{array}$ & $+0.861 *$ \\
\hline & $\begin{array}{l}5 \\
6.25\end{array}$ & $\begin{array}{l}42 \\
52.50\end{array}$ & $\begin{array}{l}33 \\
41.25\end{array}$ & $\begin{array}{l}3 \\
3.75 \\
\end{array}$ & $\begin{array}{l}23 \\
28.75\end{array}$ & $\begin{array}{l}54 \\
67.50\end{array}$ & +0.596 \\
\hline Hot water treatment & $\begin{array}{l}4 \\
5.00\end{array}$ & $\begin{array}{l}56 \\
70.00\end{array}$ & $\begin{array}{l}20 \\
25.00\end{array}$ & $\begin{array}{l}5 \\
6.25\end{array}$ & $\begin{array}{l}48 \\
60.00\end{array}$ & $\begin{array}{l}27 \\
33.75\end{array}$ & $+0.974^{*}$ \\
\hline Pest monitoring & $\begin{array}{l}7 \\
8.75\end{array}$ & $\begin{array}{l}32 \\
40.00\end{array}$ & $\begin{array}{l}41 \\
51.25\end{array}$ & $\begin{array}{l}1 \\
1.25\end{array}$ & $\begin{array}{l}10 \\
12.50\end{array}$ & $\begin{array}{l}69 \\
86.25\end{array}$ & $+0.785^{*}$ \\
\hline
\end{tabular}

*significant at 5\% level 
Table. 4 correlation coefficient between knowledge and adoption of chemical methods of IPM practices

\begin{tabular}{|c|c|c|c|c|c|c|c|}
\hline \multirow{2}{*}{$\begin{array}{l}\text { Recommended IPM } \\
\text { practices }\end{array}$} & \multicolumn{3}{|c|}{ Knowledge } & \multicolumn{3}{|c|}{ Adoption } & \multirow{2}{*}{$\begin{array}{l}\text { Correlation } \\
\text { co-efficient }\end{array}$} \\
\hline & $\begin{array}{l}\text { Fully } \\
\text { known }\end{array}$ & $\begin{array}{l}\text { Partially } \\
\text { known }\end{array}$ & $\begin{array}{l}\text { Not } \\
\text { known }\end{array}$ & $\begin{array}{l}\text { High } \\
\text { level }\end{array}$ & $\begin{array}{l}\text { Medium } \\
\text { level }\end{array}$ & $\begin{array}{l}\text { Low } \\
\text { level }\end{array}$ & \\
\hline \multirow{2}{*}{$\begin{array}{l}\text { Seed treatment } \\
\text { Balance dose of } \\
\text { fertilizer }\end{array}$} & $\begin{array}{l}10 \\
12.50\end{array}$ & $\begin{array}{l}68 \\
85.00\end{array}$ & $\begin{array}{l}2 \\
2.50\end{array}$ & $\begin{array}{l}8 \\
10.00\end{array}$ & $\begin{array}{l}36 \\
45.00\end{array}$ & $\begin{array}{l}36 \\
45.00\end{array}$ & +0.400 \\
\hline & $\begin{array}{l}24 \\
30.00 \\
\end{array}$ & $\begin{array}{l}54 \\
67.50 \\
\end{array}$ & $\begin{array}{l}2 \\
2.50 \\
\end{array}$ & $\begin{array}{l}11 \\
13.75 \\
\end{array}$ & $\begin{array}{l}67 \\
83.75 \\
\end{array}$ & $\begin{array}{l}2 \\
2.50 \\
\end{array}$ & $+0.953 *$ \\
\hline \multirow{3}{*}{$\begin{array}{l}\text { Judicious use of } \\
\text { pesticides } \\
\text { Recommended dose } \\
\text { of pesticides } \\
\text { Soil treatment }\end{array}$} & $\begin{array}{l}11 \\
13.75\end{array}$ & $\begin{array}{l}61 \\
76.25\end{array}$ & $\begin{array}{l}8 \\
10.00\end{array}$ & $\begin{array}{l}7 \\
8.75\end{array}$ & $\begin{array}{l}52 \\
65.00\end{array}$ & $\begin{array}{l}21 \\
26.25\end{array}$ & $+0.936^{*}$ \\
\hline & $\begin{array}{l}13 \\
16.25\end{array}$ & $\begin{array}{l}51 \\
63.75\end{array}$ & $\begin{array}{l}16 \\
20.00\end{array}$ & $\begin{array}{l}3 \\
3.75 \\
\end{array}$ & $\begin{array}{l}60 \\
75.00\end{array}$ & $\begin{array}{l}17 \\
21.25 \\
\end{array}$ & $+0.986^{*}$ \\
\hline & $\begin{array}{l}13 \\
16.25\end{array}$ & $\begin{array}{l}58 \\
72.50\end{array}$ & $\begin{array}{l}9 \\
11.25\end{array}$ & $\begin{array}{l}5 \\
6.25 \\
\end{array}$ & $\begin{array}{l}44 \\
55.00\end{array}$ & $\begin{array}{l}31 \\
38.75\end{array}$ & +0.700 \\
\hline $\begin{array}{l}\text { Judicious use of } \\
\text { pesticides }\end{array}$ & $\begin{array}{l}7 \\
8.75\end{array}$ & $\begin{array}{l}56 \\
70.00\end{array}$ & $\begin{array}{l}17 \\
21.25\end{array}$ & $\begin{array}{l}3 \\
3.75\end{array}$ & $\begin{array}{l}28 \\
35.00\end{array}$ & $\begin{array}{l}49 \\
61.25\end{array}$ & +0.242 \\
\hline
\end{tabular}

*significant at 5\% level

Relationship between knowledge and adoption of chemical methods of IPM practices

Table 4 reveals that the 85.00 percent respondent were partially known category about seed treatment. The 67.50 percent respondents partially known followed by 30.00 percent respondents were fully known category about balance does of fertilizers in sugarcane crop. The 76.25 percent respondents were under partially known category about the judicious use of pesticides. The 63.75 percent respondents were belonged to partially known followed by 20.00 percent respondents were belonged to not known category about recommended dose of pesticides in sugarcane crop. The 72.50 percent respondents were belonged to partially known followed by 16.25 percent respondents were belonged to fully known category about the soil treatment. The 70.00 percent respondents were under partially known category followed by 21.25 percent respondents were under not known about the judicious use of plant hormone in sugarcane crop.

The 45.00 percent respondents were belonged to both low and medium adoption of seed treatment. The 83.75 percent respondents were medium adopters the use of recommended dose of fertilizer in sugarcane crop. The 65.00 percent respondents were under medium adopters category followed by 26.25 percent respondents were under low adoption category of the judicious use of pesticides. The 75.00 percent respondents were medium adoption of recommended dose of pesticides followed by 21.25 percent respondents were low adoption category. The 55.00 percent respondents were under medium adoption of soil treatment followed by 38.75 percent respondents were low adoption categories. The 61.25 percent respondents were belonged to low adoption category followed by 35.00 respondents were belonged to medium adoption category about the judicious use of plant hormone in sugarcane crop. 
It is evident from the result that out of six the three chemical methods of IPM practices regarding knowledge were positively and highly significant correlated with the adoption level of sugarcane growers. Similar results were also reported by Nagraja et al., (2008), Vijay singh et al., (2009), Lashminarayan et al., (2010), Pillegowda (2010) were in the same line of the presents findings.

The study concluded that to the maximum knowledge gap in previous crop residues, hand picking of the insect and their destruction, hot air and water treatment, light and pheromone trap, microbial control, use of natural enemies, resistant varieties, bioagents/pesticides, application and different dose of pest etc. The maximum adoption gap in previous crop residues, intercropping, crop rotation, hot air and water treatment, hand picking of pest and their destruction, light traps, pheromone trap microbial control, natural enemies, resistant varieties, use of hormone seed treatment, soil treatment etc.

\section{References}

Jaiswal, P.K. and Tiwari Rahul Kumar. 2014. Technological Knowledge and Adoption Behaviour of Sugarcane Growers of Surguja District, Chattisgarh, South East Central India. Volume: 4 | Issue: 2 | Feb 2014 | ISSN - 2249-555X.

Kanavi, V.P. 2000. A study on the knowledge and adoption behaviour of sugarcane growers in Belgaum district of Karnataka. M. Sc. Agri.) JNKVV, Jabalpur, MP.

Lakshminarayan, M.T., Manjunatha, B.N., Nataraju, M.S. 2010. Adoption of integrated pest management practices by sugarcane farmers. Mysore J. Agri. Sci., 44(2): 376-379.

Maraddi, G.N., Hirevenkanagoudar, L.V., Angadi, J.G. and Kunnal, L.B. 2007. Extent of adoption of integrated pest management practices by sugarcane growers.

Nagaraja, M.V. Shashikumar, S. Venkateshalu. 2008. Extent of adoption of recommended sugarcane cultivation practices and constraints faced by the farmers of Bhadra command area, Karnataka. Mysore J. Agri. Sci., 42(2): 340-343.

Naik, R.D. 2005. A study on knowledge and adoption pattern on improved sugarcane practices in Bidar district of Karnataka state, M.Sc.(Ag.) Thesis, Univ. of Agril.Sci., Dharwad, India.

Pillegowda, S.M., Lakshminarayana, M.T. and Bhaskar, V. 2010. Knowledge assessment of sugarcane growers regarding recommended cultivated practices. Karnataka J. Agric. Sci., 23(3): (434-436.

Vijay Singh Godara, A.K. and Pardeep Kumar Nasib Singh. 2009. Sugarcane growers' knowledge level about integrated pest management practices in Haryana. Agri. Sci. Digest, 29(1): 16-19.

\section{How to cite this article:}

Roop Kumar, R.N. Yadav, Manoj Kumar, Amit Kumar Mishra, Akshay Kumar and Kshitij Parmar. 2017. Impact of Knowledge on Adoption of Integrated Pest Management Practices by Sugarcane Growers. Int.J.Curr.Microbiol.App.Sci. 6(3): 348-354. doi: https://doi.org/10.20546/ijcmas.2017.603.039 